\title{
EARLY DEVELOPMENT AND GROWTH OF STERLET (ACIPENSER RUTHENUS) IN THE CZECH REPUBLIC
}

\author{
J. Rybnikár, M. Prokeš, J. Mareš, M. Cileček
}

Received: March 8, 2011

\begin{abstract}
RYBNIKÁR, J., PROKEŠ, M., MAREŠ, J., CILEČEK, M.: Early development and growth of sterlet (Acipenser ruthenus) in the Czech Republic. Acta univ. agric. et silvic. Mendel. Brun., 2011, LIX, No. 5, pp. 217-226

Growth rate of sterlet larvae and juveniles during 2008 and 2009 was studied under experimental and farming conditions in the Czech Republic. The embryos hatched when reaching a mean total length (TL) of $9.0 \mathrm{~mm}$. Larvae were fed by living food, with a gradual transition to dry diet. The exogenous feeding and the larval period of ontogeny started at DAH 9 (day after hatching) reaching TL of 15$17 \mathrm{~mm}$ accompanied by melanin plug exclusion. Towards the end of larval period (DAH 39-43, TL 50-58 mm), the embryonic finfold disappeared and the formation of fin apparatus was nearly completed. During the larval and early juvenile development, daily increments of TL and weight (w) ranged between $0.33-4.23 \mathrm{~mm} . \mathrm{d}^{-1}$ and $0.0018-1.6400 \mathrm{~g} . \mathrm{d}^{-1}$, respectively. The specific growth rate (SGR) ranged from 25.65 to $2.73 \%$. $\mathrm{d}^{-1}$. Growth intensity and length parameters are similar to the Starry sturgeon, lower than those of the Siberian sturgeon and Russian sturgeon and significantly lower than at Beluga sturgeon. Sterlet's Fulton weight condition factor (FWC) was higher than in the Siberian and Starry sturgeon. The development was also observed on the basis of morphological changes. The larval development could be divided into six steps.
\end{abstract}

early ontogeny, specific growth rate, length-weight relationship, factor of weight condition

The sterlet (Acipenser ruthenus L.) is the smallest native freshwater species of the family Acipenseridae, subfamily Acipenserinae for the Czech Republic (Baruš, Oliva et al. 1995). It ranges in the Danube Slovakian stretch, from where it spreads, or spread into the Morava River on the territory of the Czech Republic. The following experts studied the growth of sterlet in the Slovak Danube natural stretch - Kovrižnych (1988), Stráňai (1992) and Kováč (1997). Baránek et al. (2004, 2006); Jirásek et al. (1997); Krupka et al. (2000); Mészáros et al. (2004) and Prokeš et al. (1997a, 1999, 2000a,b, 2003b) examined, under experimental and intensive production of the Czech and Slovak Republics, the early ontogeny, larval and juvenile growth and rearing. The current status of sterlet in the Slovak Republic, including information on its pisciculture and stocking in the Danube, was stated by Holčík et al. (2006). Current sterlet farming, rearing and production in the
Czech Republic has been conducted since 1995 in the Fishery Unit Pohořelice, Inc. (Rybníkářství Pohořelice, a. s.) (Baránek et al., 2004; Prokeš et al., 2003b). Initial import of fertilized eggs and larvae and juvenile rearing of six sturgeon species, including sterlet (Huso huso, Acipenser stellatus, A. baerii, A.ruthenus, A.gueldenstaedtii and Polyodon spathula) was carried out in the Mydlovary hatchery, Hluboká n. Vltavou, a. s. (fishery enterprise) in 1994-1996 (Hohausová et al., 1996; Jirásek et al., 1997; Klívar, 1996; Prokeš et al., 1996, 1997b,c, 1999, 2000a,b, 2002, 2003a) and later in the Research Institute of Fish Culture and Hydrobiology (RIFCH) in Vodňany (Linhart et al., 2000, 2003, Policar et al., 2004, Gela et al., 2008, Flajšhans et al., 2009, Pšenička et al., 2010 and others).

The aim of this study was to monitor the ontogeny and growth of embryos and larvae of sterlet reared under controlled conditions in the Czech Republic 
and to compare collected data with the relevant data, available both in this country and abroad. The data on development and growth of sterlet larvae in the Czech Republic, not yet published, should be used mainly for improvement of fry and fingerlings rearing of this species, as well as for purposes of their introduction into natural aquatic ecosystems. The natural sterlet population is currently endangered in the upper Danube and its tributaries.

\section{MATERIAL AND METHODS}

The monitoring of sterlet early ontogeny and growth took place in 2008 and 2009. The material of embryos (after hatching called also eleuteroembryos or prelarvae) and larvae (after DAH 9) was obtained from artificial brood fish stock reared at hatchery Velký Dvi̊r, Fishery Unit Pohořelice, Inc. (Rybníkářství Pohořelice, a.s.). In order to determine the Daily Feeding Ratio (DFR in \% of fish weight), larvae were weighted regularly in two or three-day intervals. Along with the larvae measuring, samples were collected for fixation in the $4 \%$ formaldehyde solution. Three months after, once the mass stabilization had finished, all fixed fish were measured and weighted. The following features were determined: total length (TL in $0,1 \mathrm{~mm}$ ) and weight (w in $0,0001 \mathrm{~g}$ ).

\section{8}

For experimental purposes, sturgeons hatched on 9 May 2008 at the hatchery Velký Dvůr, Rybníkářství Pohořelice, Inc. at water temperature of $18{ }^{\circ} \mathrm{C}$. In the age of DAH 5 these were placed at the Section of Fishery and Hydrobiology MENDELU (Mendelova univerzita v Brně) in a recirculation system consisted of plastic trough, filter, aeration and heater. Trough volume was $100 \mathrm{l}$ and brood density at the beginning of the experiment was 17 pcs/l. Measurements of water temperature, oxygen saturation percentage and $\mathrm{pH}$ were performed every morning before feeding. Used devices: WTW Multi 340i and WTW $\mathrm{pH} 315 \mathrm{i}$. The temperature ranged from $17^{\circ} \mathrm{C}$ on the initial day towards $19{ }^{\circ} \mathrm{C}$ at the end of experiment, without fluctuation. The oxygen content ranged 63\%-91\% throughout the whole monitoring. The minimum $\mathrm{pH}$ value was 7.5 , maximum 8.4 ; without high fluctuation. Feeding was not initiated until the DAH 5. We applied nauplii brine shrimps (Artemia salina) SANDERS (50\% protein and $20 \%$ fat) brands. Brines were incubated at the Section of Fishery and Hydrobiology MENDELU. After incubation, the larvae were either fed immediately or the nauplii kept refrigerated at $4{ }^{\circ} \mathrm{C}$ and fed during maximum 12 hours storage. Along with brine shrimp, the perla larva proactive 5 (62\% protein and $11 \%$ fat) was fed, as well.

\section{9}

The monitoring was performed at hatchery Velký Dvưr, Rybníkářství Pohořelice Inc. Fish embryos began to hatch on 20 April 2009 at water temperature of $14.5{ }^{\circ} \mathrm{C}$. After hatching, they were transferred to flow-through troughs. Trough water source was a small pond free of fish brood. Foam filter prevents the intrusion of organisms and contaminants. Larvae and juvenile rearing took place in the hatchery, from which the samples were taken. First, the larvae were fed ad libidum with sorted zooplankton (200-2000 $\mu \mathrm{m}$ ), later on with dry diet, which was applied to advanced larvae and juveniles by means of automatic feeder over the period of 24 hours. Early development and intervals of ontogeny were classified after Lange et al. (1974); Detlaf et al. (1981); Balon (1986); Peňáz (1995, 2001) and Pavlov (2007). The monitoring included the final part of embryonic period (E), the whole larval period (L) divided into 6 steps (L1-L6), and the initial part of juvenile period (J). Growth was analyzed via absolute and relative increments (DI), specific growth rate, $\mathrm{SGR}=\left[\left(\ln \mathrm{w}_{1}-\ln \mathrm{w}_{0}\right)\right.$. 100], Fulton's weight condition factor, FWC $=\left(\mathrm{w} .10^{5}\right)$ . $\mathrm{TL}^{-3}$. Calculations of length-weight relationship $\left(\mathrm{w}=\mathrm{a} . \mathrm{TL}^{\mathrm{b}}\right)$ and polynomial growth curves (t:TL and t:w). All abovementioned parameters always used total length (TL). For needs of production indicators, the Daily Feeding Ratio (DFR) was calculated. The Microsoft Excel program was used for graphs, regression curves and calculations.

\section{RESULTS AND DISCUSSION}

The following changes were found in the length, weight and morphology of sterlet during subsequent age (DAH) of early ontogeny:

\section{8}

DAH 5, E, TL = 13.1-5.3 mm, w = 0.0122-0.0185 g, FWC $=0.4007-0.6390$.

Still no food was visible in the digestive tract of free embryos; melanin plugs were apparently formed at six individuals in the spiral part of their intestines. There were apparent the pectoral and ventral fins. Individuals of different size had approximately the same weight - therefore the relationship between length and weight was not significant (Table I, Fig. 1A). Values of Fulton's weight condition factor (FWC) decreased with increasing total length (Fig. 1A).

\section{DAH 10, Ll, TL = 14.5-18.6 mm, $\mathrm{w}=0.015-0.0327 \mathrm{~g}$, FWC $=0.3699-0,6517$.}

There was a food visible in larvae digestive tract, $3 \%$ of specimen had not received any food, so far. The differentiation of unpaired finfold was more pronounced. Ventral fin margin did not exceed the pre-anal finfold. The end of the notochord was straight. The melanin plugs were floating in water at the trough bottom. The individuals found themselves in the so-called critical period, with respect to the need for suitable food. (Table I, Fig. 1B). 
I: Total Length (TL in mm), Weight ( $w$ in g), Fulton's Factor of Weight Condition (FWC), Length-Weight Relationship and Specific Growth Rate (SGR) in free embryos and larvae of sterlet (Acipenser ruthenus) in 2008 and 2009. Explanations: DAH = Day After Hatching, TL = Total Length, $w=$ Weight, FWC = Factor of Weight Condition, a, $b=$ Regression Coefficients, $R^{2}=$ Determination Coefficient, $S G R=$ Specific Growth Rate, $S D=$ Standard Deviation

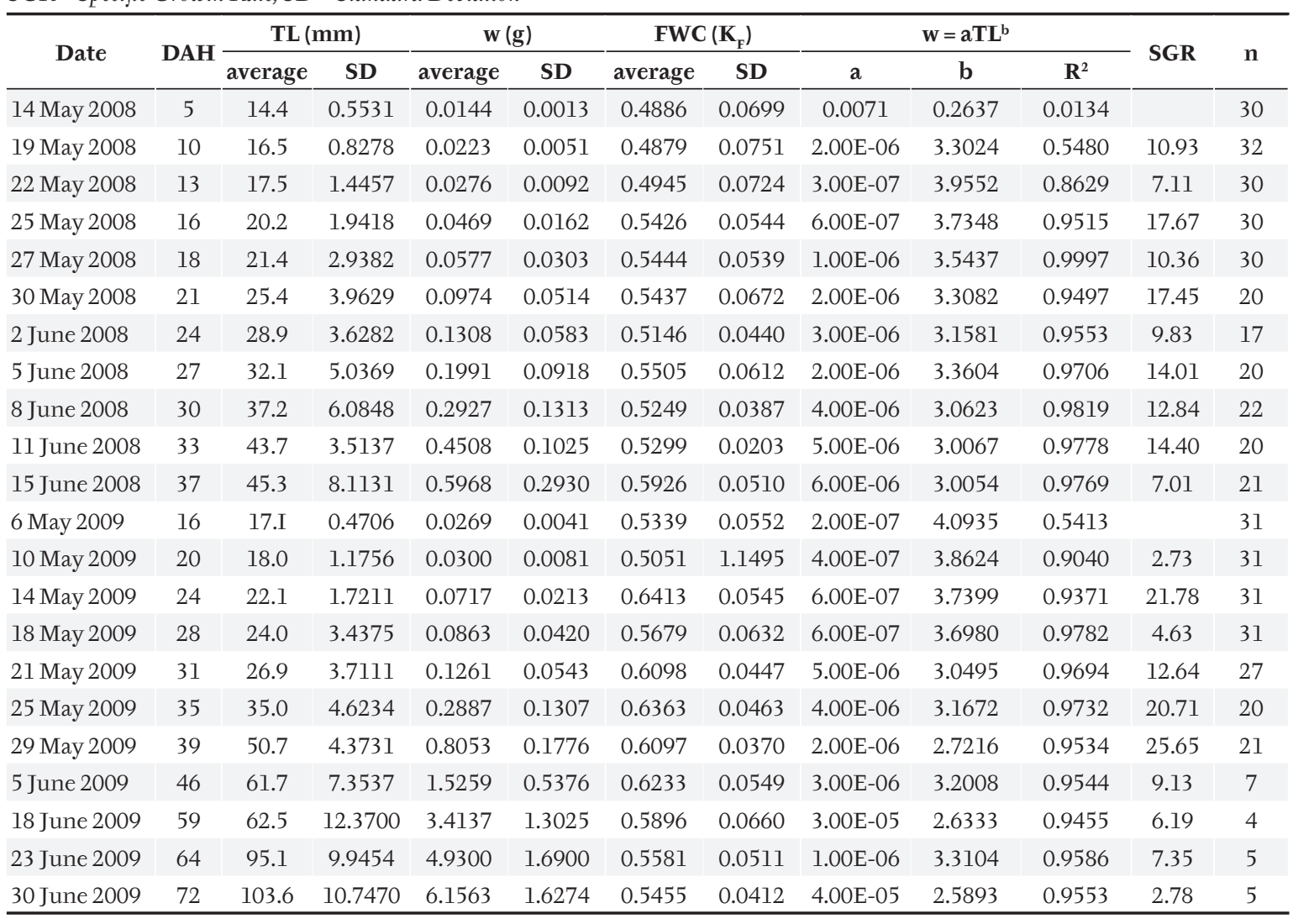

DAH 13, L2, TL $=14.8-20.5 \mathrm{~mm}, \mathrm{w}=0.0131-0.0466$, $\mathrm{FWC}=0.3594-0.5928$.

The food was visible in digestive tract of all larvae. Differentiation of unpaired finfold continued, there were slight rudiments of dorsal and anal fins. Notochord was slightly bent upwards. The critical period continued; the minimum FWC value was still the lowest, the average value was, however, slightly higher (Table I, Fig. 1C).

DAH 16, L2-L3, TL = 16.6-24.1 mm, $\mathrm{W}=0.0195-0.081 \mathrm{~g}, \mathrm{FWC}=0.3815-0.6272$.

All the morphological changes detected in previous sample were more conspicuous. Ventral fin exceeded the edge of unpaired finfold (Table I, Fig. 1D).

DAH 18, L2-L4, TL = 16.7-28.8 mm, $\mathrm{W}=0.0235-0.1437 \mathrm{~g}, \mathrm{FWC}=0.4563-0.6346$.

Ventral fin exceeded the edge of unpaired finfold significantly. Pre-anal finfold remnants still were present. Mesenchyme condensation in the place of formation lower lobe of caudal fin was first noticed (Table I).
DAH 21, L3-L5, TL $=20.8-35.3 \mathrm{~mm}$, $\mathrm{W}=0.0423-0,2452 \mathrm{~g}, \mathrm{FWC}=0.4329-0.6817$.

Vestiges of the finfold in front of the anal fin are no longer detectable, they are still present only between the dorsal plates. Mesenchyme condensation occurred on the future lower lobe of caudal fin (Table I).

DAH 24, L4-L5, TL = 24.1-38.4 mm, $\mathrm{W}=0.0770-0.3031, \mathrm{FWC}=0.4421-0.5984$.

Still, there were unpaired finfold remnants between dorsal plate tags. Either the lateral line plates way the lower lobe of the caudal fin has been formed, yet. Ventral line plates are already created (Table I).

DAH 27, L4-L6, TL $=22.8-40.3, \mathrm{w}=0.0554-0.3502$, $\mathrm{FWC}=0.4341-0.6320$.

Unpaired finfold still remains between dorsal plate tags. No rays are formed in the caudal and anal fins. Lateral line plates' formation is finished, dorsal fin rays creation began (Table I), (Fig. 2). 


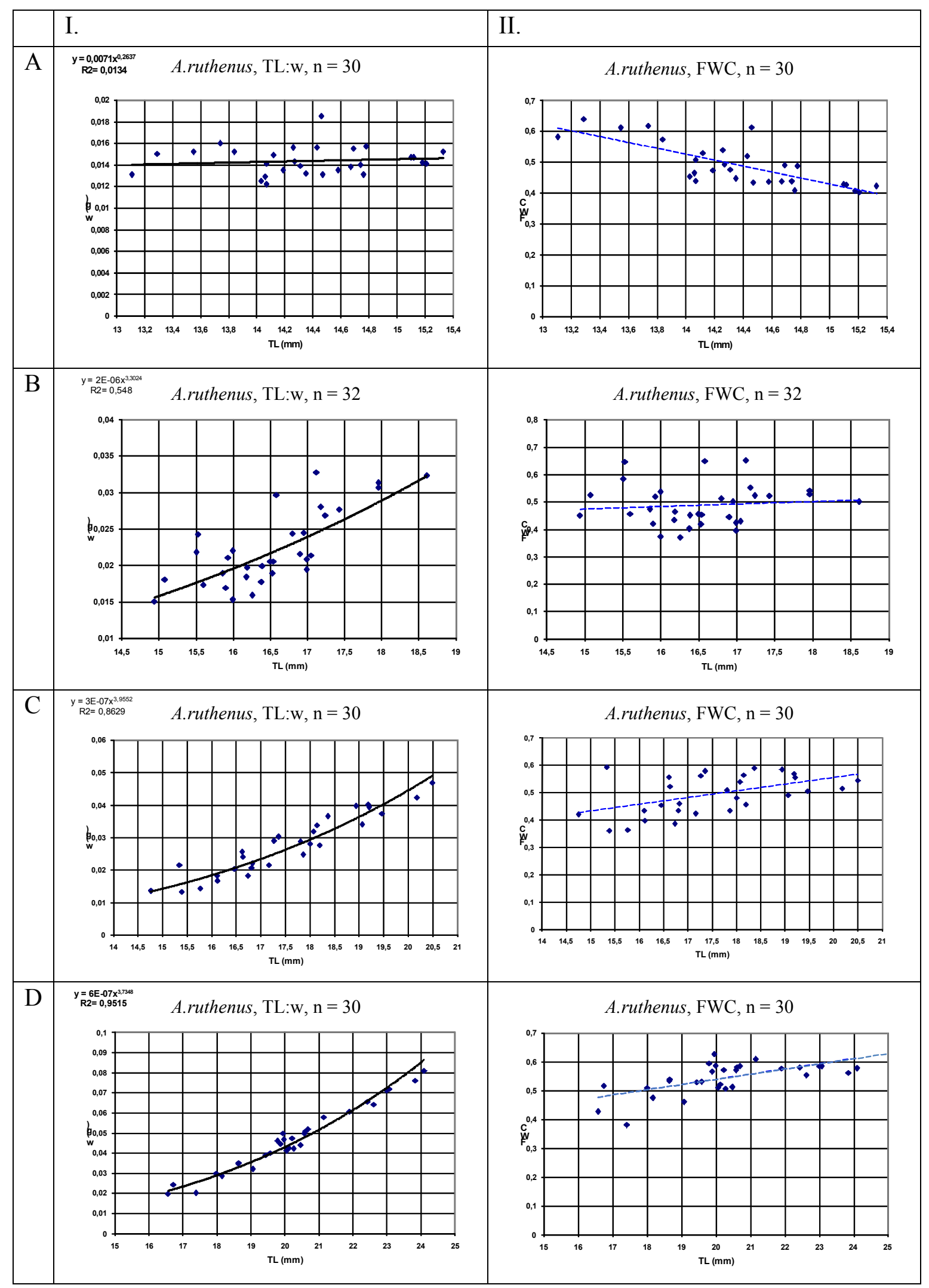

1: Length-Weight Relationship (I) and Weight Condition Values (FWC)(II) for different sized individuals 2008; A - DAH 5, B - DAH 10, C - DAH 13, D-DAH 16 


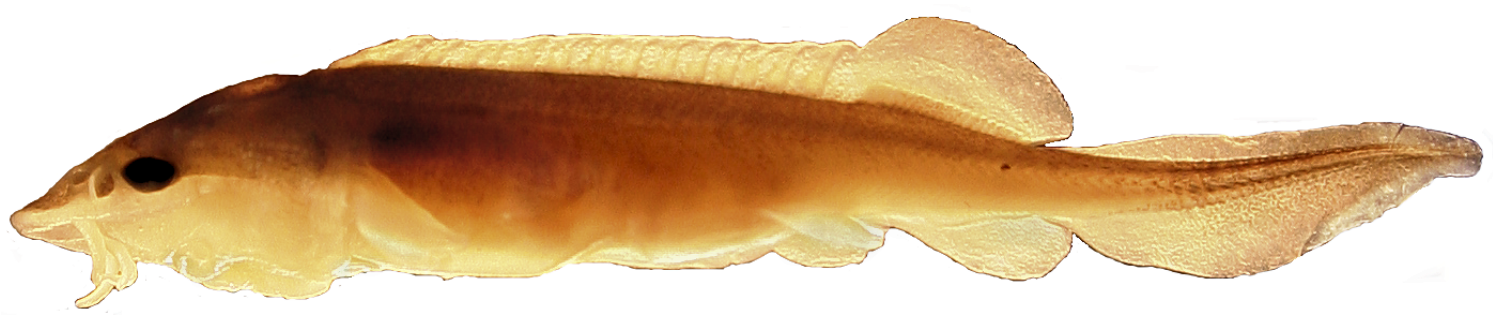

2: $\mathrm{DAH} 27, \mathrm{L3}, \mathrm{TL}=30,74 \mathrm{~mm}, w=0,1723 \mathrm{~g}$

- no rays formed in the caudal and anal fins, lateral line plates' formation finished

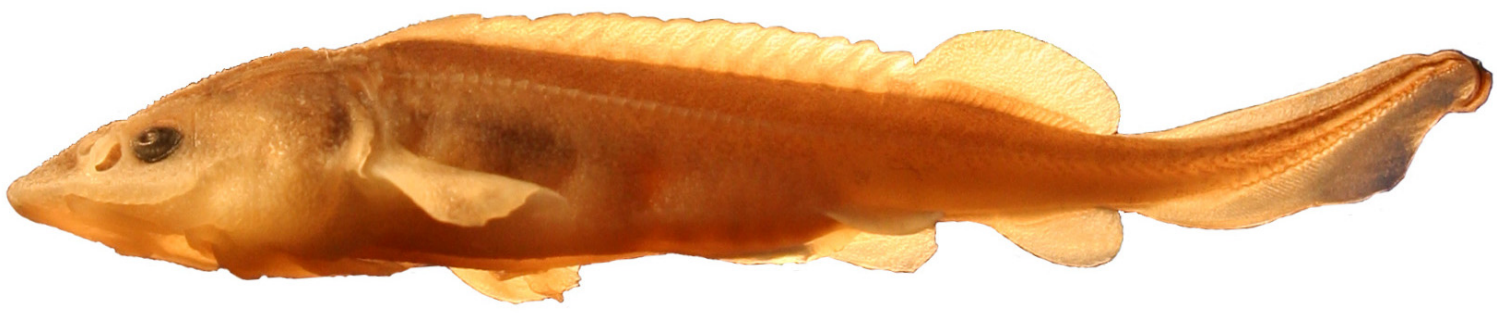

3: $\mathrm{DAH} 30, \mathrm{~L} 4, \mathrm{TL}=35,34 \mathrm{~mm}, w=0,2250 \mathrm{~g}$

- formation of rays in dorsal and caudal fin, dorsal plate tags almost free of finfold remnants

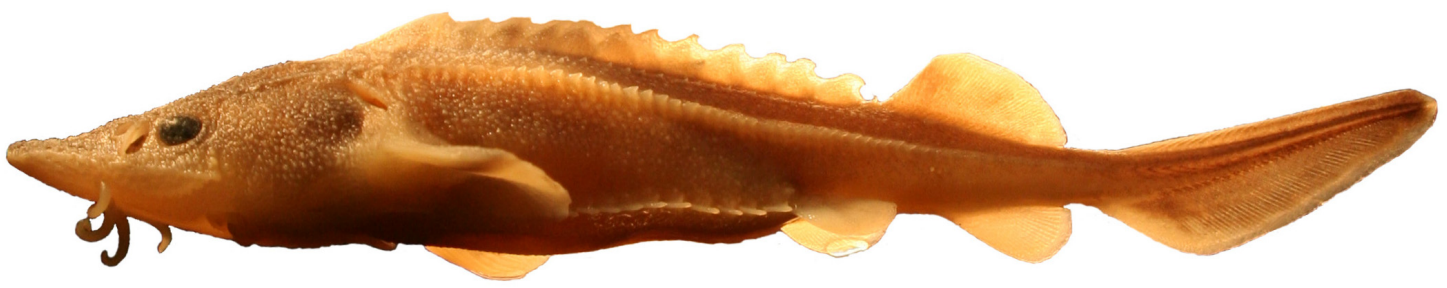

4: $\mathrm{DAH} 38, \mathrm{~L} 5, \mathrm{TL}=57,04 \mathrm{~mm}, w=1,0108 \mathrm{~g}$

- dorsal, caudal and anal fin rays extended up to the edge, rays of ventral fins visible, not extended to the edge

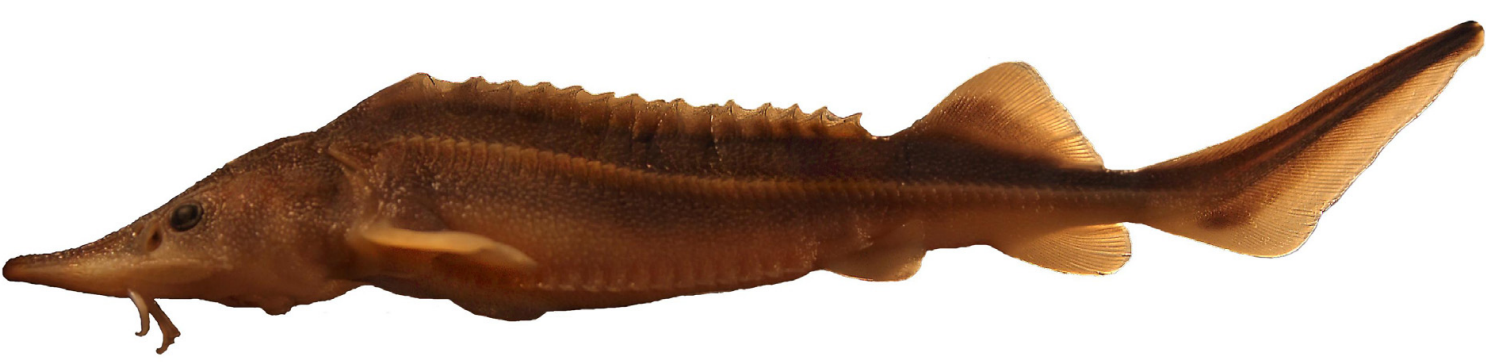

5: $\mathrm{DAH} 69, \mathrm{~J}, \mathrm{TL}=111,4 \mathrm{~mm}, w=7,3502 \mathrm{~g}$

- fulcrae reached almost to the end of the dorsal edge of caudal fin, rays in all fins almost created

\section{DAH 30, L4-L6, TL = 24.0-47.6, $\mathrm{w}=0.0751-0.5662$, FWC $=0.4510-0.5938$, L4-L6.}

Dorsal plate tags are almost free of finfold remnants, that persist in front of the dorsal fin base. Formation of rays in dorsal and caudal fin. Lateral line plates are already completed in some individuals, measuring of standard length (SL) was possible. Rays formation is less conspicuous in the abdominal fins and had not proceeded in caudal fin, yet (Table I), (Fig. 3). $\begin{aligned} \text { DAH 33, L5-L6, TL } & =35.0-49.3, \mathrm{w}=0.2284-0.6202, \\ \text { FWC } & =0.4962-0.5706 .\end{aligned}$

All three plate lines, except of the lateral line, are completed. Dorsal and caudal fin rays extended up to the edge. No rays could be seen in ventral fins, yet.

DAH 37, L5-J, TL $=26.2-63.7, \mathrm{w}=0.0953-1.2625$, $\mathrm{FWC}=0.4884-0.7139$.

Lateral line was not completed, yet. Fulcral scales could be seen clearly in the-caudal fin. Dorsal, 
caudal and anal fin rays extended up to the edge. The rays of ventral fins were visible, however not extended to the edge. The lower lobe of caudal fin had not developed, yet (Table I), (Fig. 4).

Other recorded and calculated parameters, i.e. average values and standard deviation, TL, w and FWC, specific growth rate (SGR), coefficients ( $a, b$, $\mathrm{R} 2$ ), length-weight relationship, sample frequency and date of sampling are listed in (Table I).

\section{9}

As for development, the 2009 samples coincided with 2008 material, however their sampling proceeded until higher development stage. Description of the development in 2009 continued from the point, at which the 2008 samples terminated, however these two partly overlap (see Table I).

DAH 46, L6-J, TL $=50.1-71.9 \mathrm{~mm}$, $\mathrm{W}=0.7356-2.1564 \mathrm{~g}, \mathrm{FWC}=0.5501-0.6874$.

Rays did not fully reach to the edges of caudal, dorsal and anal fins, neither to the edge of ventral fins. Dorsal plate tags are bent backwards. The caudal fin lower lobe is not formed, yet. Fulcral scales are approximately at the half of the caudal fin.

DAH 59, J, TL = 70.6-94.2 mm, $\mathrm{W}=1.9882-4.6724 \mathrm{~g}, \mathrm{FWC}=0.5205-0.6766$.

Rays of all fins reached almost to the edge. The caudal fin lower lobe is formed clearly. Pronounced pigmentation is noticeable throughout the body.

DAH 64, J, TL = 78.4-102.6 mm, w = 2.7015-7.0792 g, $\mathrm{FWC}=0.5487-0.6758$.

The differentiation of caudal fin lobes was proceeding. Significant skin pigmentation and pronounced cutaneous formation is perceptible.

DAH 69, J, TL = 89.5-114.7 mm, w = 4.3775-7.7670 g, $\mathrm{FWC}=0.5112-0.6116$.

Caudal fin lobes differentiation continued. Fulcrae reached almost to the end of the dorsal edge of caudal fin. Rays in all fins were almost created (Fig. 5).

As in the previous case, all other identified and calculated parameters are listed in Table I.

By the observation of morphological and morphometric changes and its comparison with the data of Krupka et al. (2000), we obtained results contributing to a more detailed knowledge of the early development of the sterlet. During its development process, the sterlet undergoes through two larval steps only, according to Krupka et al. (2000). As our results confirm and on the ground of fin structure changes determined, the larval period can be divided into six steps. Between TL and w, no significant regression was observed on the fifth day after hatching (DAH 5) (Fig. 1A). Initially, Fulton's weight condition coefficient value decreased with the size of individuals (Table I, Fig. 1A), which is normal, since fish still had the yolk sac, using endogenous nutrient sources for the weight and length growth and these nutrients' metabolic waste and energy consumption reduced fish specific weight, but not the specific length. At the time of decrease, there were still no exogenous food intake in the analyzed sample of the approximate size of $15 \mathrm{~mm}$ TL, the specific weight began to rise gradually, afterwards (Table I, Fig. 1B). On the thirteenth day after hatching (DAH 13), significant positive regression between TL and $\mathrm{w}$ of larvae was found out (Table I, Fig. 1C). Weight condition factor and length of larvae increased significantly (Table I, Fig. 1C). In terms of larvae morphological development degree, these fell within the second larval step (L2). Particularly, gill respiratory system development was noted, as well as slipping-out of mouth, located at the base of head, during feeding, formation of paired pelvic base and unpaired dorsal and anal fin. Back string end section was slightly bent upwards and the intestines of all individuals were considerably filled with food. End of larval development period was observed at DAH 37-46 (TL 50-56 mm). Except of the complete formation of lower lobe of caudal fin, all remnants of unpaired finfold completely disappeared. Development of rays continued in unpaired fins during this period. The growth intensity of sterlet during the interval from hatching to the end of larval period was considerably high. The original TL average of $9 \mathrm{~mm}$, observed after hatching, increased in this period 6 times on average (to $54 \mathrm{~mm}$ ), and initial weight of $0.01 \mathrm{~g}$ increased almost 100 times (to $0.98 \mathrm{~g}$ ). It is apparent from the above-stated data, that the maximum length and weight changes occurred in the period after the intake of exogenous food initiated. The lowest weight condition rate was found in individuals, those TL was $15-17 \mathrm{~mm}$. The size and growth intensity of free embryos and larvae in the period from hatching to the end of larval development period was significantly affected by the species-specific growth potential, which is the smallest one among sturgeons reared in the Czech Republic (Gisbert et al., 2000). Under the conditions of the Czech Republic, size and growth intensity parameters of sterlet are, for this reason, similar to those of the Starry sturgeon (Klivar, 1996), lower than the Siberian sturgeon (Prokeš et al., 1996) and Russian sturgeon (Prokeš et al., 1997b) and significantly lower compared to Beluga sturgeon (Hohausová et al., 1996). However, the Fulton weight condition factor was, in case of sterlet, higher than that of the Starry sturgeon and Siberian sturgeon. The observations we found were similar to data presented by Dettlaff et al. (1981), Mil'stein (1982), Hochleithner (1993), Jirásek et al. (1997), Krupka et al. (2000) and Wegner et al. (2009). 


\section{SUMMARY}

The aim was to investigate the early ontogeny and growth of sterlet reared under controlled conditions. The free embryos and larvae hatched at the hatchery Velký Dvůr, Rybníkářství Pohořelice Inc. were used for the monitoring which took place in 2008 and 2009. During 2008 the sterlet embryos, larvae and juveniles were reared at the Section of Fishery and Hydrobiology MENDELU. Rearing took place in trough with recirculation system. Larvae were fed by the brine shrimps (Artemia salina) and perla larva proactive 5 dry feed. In 2009, the monitoring took place at hatchery Velký Dvưr, Rybníkářství Pohořelice Inc. The larvae were fed ad libidum with sorted zooplankton, later on with dry diet. Samples collected were stored in the $4 \%$ formaldehyde solution. Three months after, once the mass stabilization had finished, all fixed embryos, larvae and juveniles year 2008 and 2009, were individually measured and weighed (TL in $0.1 \mathrm{~mm}$, and w in $0.0001 \mathrm{~g}$ ). Sampling was initiated in 2008 in age of 5 days after hatching DAH 5 and ended at the age DAH 37 with eleven samples. The 2009 sampling ended on DAH 69. Each sample corresponds approximately to one periodic development jump. On DAH 10 larvae already fed exogenous food were classified as falling within $1^{\text {st }}$ larval step. On DAH 37, larvae, whose larval features were vanishing gradually, fell within the $6^{\text {th }}$ larval step, i.e. to the last larval step. Transition to the juvenile development period occurred at TL 50-54 mm. The fin apparatus of juveniles was formed completely, except of the lower lobe of caudal fin, whose development continued also during the initial part of the juvenile period of development. On DAH 5, no significant regression was observed in the total length (TL) and weight $(\mathrm{w})$ of free embryos. Exogenous feeding did not occur so far. On DAH 13, significant positive regression between TL and w was detected. Weight condition factor increased significantly along with larvae length. The TL of $9 \mathrm{~mm}$ observed after hatching increased during larval period 6 times on average (to $54 \mathrm{~mm}$ ) and $0.0100 \mathrm{~g}$ weight increased almost 100 times (to $0.98 \mathrm{~g}$ ). The maximum length and weight changes occurred in the period after the exogenous feeding intake initiation. The lowest weight condition factor was found in individuals with the TL of $15-17 \mathrm{~mm}$. Size of free embryos and larvae, as well as growth intensity were significantly affected by the species-specific growth potential, which is the lowest one among sturgeons reared in the Czech Republic. We found that size and growth intensity of sterlet larvae are in the Czech Republic similar to the Starry sturgeon, lower than Siberian sturgeon and Russian sturgeon and significantly lower than that of Beluga sturgeon. However, the Fulton weight condition factor during early ontogeny was, in case of sterlet, higher than the Starry sturgeon and Siberian sturgeon.

Acknowledgement

The authors thank to Rybníkářství Pohořelice, Inc., for allowing the observation and offering sterlet research material. The work was performed within the Institutional Research Plan MSM6215648905 "Biological and Technological Aspects of Sustainability of Controlled Ecosystems and Their Adaptability to Climate Change" granted by the Ministry of Education, Youth and Sport of the Czech Republic. Financial support was provided by the Ministry of Agriculture - Project Grant NAZV QH 71305 "Development of New Methods of Rearing Selected Promising Species for Aquaculture Using Non-traditional Technologies".

\section{REFERENCES}

BALON, E. K., 1986: Saltatory ontogeny and evolution. Revista di Biología, 79(2): 151-190.

BARÁNEK, V., 2004: Růstové vlastnosti jesetera malého a jesetera sibiřského v experimentálních a rybničních podmínkách [Growth rate of sterlet and Siberian sturgeon in experimental and pond condition]. Thesis, MUAF in Brno, 93 pp.

BARÁNEK, V., PROKEŠ, M., BARUŠ, V., PEŇÁZ, M., MAREŠ, J., SPURNÝ, P. \& NĚMEC, R., 2004: Růst jesetera malého (Acipenser ruthenus) v podmínkách Rybníkářství Pohořelice [Growth of sterlet (Acipenser ruthenus) under conditions of Fishery Unit Pohořelice Inc.]. In: SPURNÝ, P. (ed.), Sb. “55 years of the study programme of the fishery specialization at Mendel University of Agriculture and Forestry in Brno". DFH MUAF in Brno 2004, pp. 119-127 (in Czech, with English abstract).
BARÁNEK, V., PROKEŠ, M., BARUŠ, V., PEŇÁZ, M., CILEČEK, M., MAREŠ, J., JIRÁSEK, J. \& SPURNÝ, P., 2006: Srovnání růstu juvenilního (1+) jesetera malého (Acipenser ruthenus) při použití experimentální a komerční diety [Growth comparison of the $1+$ juvenile sterlet (Acipenser ruthenus) by using experimental and commercial diet]. In: VYKUSOVÁ, B. (ed.), Sb. The 9th Czech Conference of Ichthyology. University of South Bohemia in České Budějovice, Research Institute of Fish Culture and Hydrobiology in Vodňany 2006, pp. 8-11 (in Czech, with English abstract).

BARUŠ, V., OLIVA, O. (eds.) etal., 1995: Fauna ČRa SR, sv.28/1. Mihulovci-Petromyzontes a ryby-Osteichthyes (1) [Fauna of the Czech Republic and the Slovak Republic, Vol. 28/1. Lampreys Petromyzontes and fishes Osteichthyes (1)]. Academia Praha, 623 pp. ISBN 80-200-0500-5 (in Czech, with English summary). 
DETTLAFF, T. A., GINSBURG, A. S., SCHMALHAUSEN, O.I., 1981:Razvitie osetrovykh ryb. Sozrevanie ootsitov, oplodotvorenie, razvitie zarodyshei i predlichinok [Development of Sturgeon Fishes, Oocyte Maturation, Fertilization and Development of Embryos and Prelarvae]. Izd. Nauka, Moskva, 224 pp. (in Russian).

FLAJŠHANS, M., HULÁK, M., KAŠPAR, V., RODINA, M. \& KOCOUR, M., 2009: Metodika uchování genetických zdroju ryb v živé genové bance. [Methodology of conservation of fish genetic resources in a live gene bank]. Methodology edition (Technology Series), Faculty of Fisheries \& Protection of Waters University of South Bohemia Vodňany, 2009, No. 91, 25 s. ISBN 978-80-8588791-4 (in Czech).

GELA，D., RODINA，M., LINHART, O., 2008: Řizená reprodukce jeseterů (Acipenser) [The artificial reproduction of the sturgeons]. Methodology edition (Technology Series), Research Institute of Fish Culture and Hydrobiology University of South Bohemia Vodňany 2008, no. 78, 24 s. ISBN 978-80-85887-62-4 (in Czech).

GISBERT, E., WILLIOT, P. \& CASTELLÓ-ORVAY, F., 2000: Influence of egg size on growth and survival of early life stages of Siberian sturgeon (Acipenser baerii) under small scale hatchery conditions. Aquaculture 183: 83-94.

HOHAUSOVÁ, E., KLÍVAR, D. \& PROKEŠ, M., 1996: Růst larev a juvenilních jedinců 0+ vyzy velké (Huso huso) v akvakulturních podmínkách České republiky [Growth of 0+ Beluga (Huso huso) larvae and juveniles in aquaculture conditions of Czech Republic]. In: Sb. The 2nd Czech Conference of Ichtyology. Research Institute of Fish Culture and Hydrobiology University of South Bohemia in Vodňany 1996, pp. 151-155 (in Czech, with English abstract).

HOCHLEITHNER, M., 1993: Early growth of different sturgeon species (Acipenseridae) under aquaculture conditions. In: Abstract Bulletin - International Symposium on Sturgeons. Moscow, VNIRO, pp. 72-73.

HOLČÍK, J., KLINDOVÁ, A., MASÁR, J. \& MÉSZÁROS, J., 2006: Sturgeons in the Slovakian rivers of the Danube River basin: an overview of their current status and proposal for their conservation and restoration. J. Appl. Ichtyol. 22 (Suppl. 1) (2006): 17-22.

JIRÁSEK, J., SPURNÝ, P., MAREŠ, J., ONDRA, R., PEŇÁZ, M., BARUŠ, V. \& PROKEŠ, M., 1997: Biologické a ekologické aspekty intenzivního odchovu plůdku jeseterů v podmínkách České republiky [Biological and Ecological Aspects of Intensive Breeding of Sturgeon Fry Under Conditions of the Czech Republic]. Annual Report, Grant project no. 509/94/0345, Grant Agency of the Czech Republic. MUAF in Brno and Institute of Landscape Ecology AS CR in Brno, 143 pp (in Czech).

KLIVAR, D., 1996: Růst plůdku jesetera hvězdnatého (Acipenser stellatus) v akvakulturním chovu [Growth of stellate sturgeon (Acipenser stellatus) fingerlings in aquaculture rearing]. In: Sb. The 2nd Czech Conference of Ichtyology. Research Institute of Fish Culture and Hydrobiology University of South Bohemia in Vodňany 1996, pp. 156-161 (in Czech, with English summary).

KOVÁČ, V., 1997: Age and growth of sterlet (Acipenser ruthenus L.) from the middle Danube. Acta Zool. Univ. Comenianae, Vol. 41: 39-42.

KOVRIŽNYCH, J. A., 1988: Age and growth of the sterlet (Acipenser ruthenus Linnaeus, 1758) in the Czechoslovak stretch of the Danube. Práca Laboratória Rybárstva a Hydrobiológie, Bratislava, 6: 101-114.

KRUPKA, I., MASÁR, J. \& TURANSKÝ, R., 2000: Raný vývoj jesetera malého (Acipenser ruthenus Linnaeus, 1758) [Early ontogeny of sterlet (Acipernser ruthenus Linnaeus, 1758)]. Pol'nohospodárstvo [Agriculture], 46(5): 387-399 (in Slovak, with English abstract).

LANGE, N. O., DMITRIIEVA, E. N., SMIRNOVA, E. N. \& PEŇÁZ, M., 1974: Metodika isledovaniya morfologicheskikh osobennostei razvitiya ryb $\mathrm{v}$ zarodyshevyi, lichinochnyi a mal'kovyi periody [Methods of studying the morphological peculiarities of fish development during the embryonic, larval and juvenile periods]. In: Volskis, R.S. (ed.), Tipovyie metodiki issledovaniia produktivnosti vidov ryb v predelakh ikh arealov. Vilnjus, B, pp. 56-71 (in Russian and English).

LINHART, O., GELA, D. \& RODINA, M., 2000: Umèlá reprodukce veslonosa amerického (Polyodon spathula) [Artificial reproduction of paddlefish (Polyodon spathula) ]. Research Institute of Fish Culture and Hydrobiology University of South Bohemia in Vodňany, Methodology edition, 64, pp. 1-15, ISBN 80-858-8734-7 (in Czech).

LINHART, O., COSSON, J., MIMS, S. D., RODINA, M., GELA, D. \& SHELTON, W. L., 2003: Effects of ionts on the motility of fresh and demembranate sperm of common carp (Cyprinus carpio) and paddlefish (Polyodon spathula). Fish Physiology and Biochemistry, 28: 203-205.

MÉSZÁROS, J., KOHÚT, J., JANOUŠOVÁ, M., VITEK, J., HUSZÁR, R., 2004: Niektoré aspekty technológie umelého odchovu jesetera malého [Some technological aspects of artificial breeding of sterlet in Slovakia]. Proceedings of the conference „50 years of the study programme of the fishery specialization at Mendel University of Agriculture and Forestry in Brno". Mendel University of Agriculture and Forestry in Brno, Department of Fisheries and Hydrobiology, pp. 85-89 (in Slovak, with English abstract).

MIL'STEIN, V. V., 1982: Osetrovodstvo [Sturgeon culture]. Legkaia i pishchevaia promyshlennost', Moskva 1982, 151 pp. (in Russian).

PAVLOV, D. A., 2007: Morphological variation in the early ontogeny of teleost fishes. Moscow, GEOS 2007, 263 pp. (in Russian, with abstract in English).

PEŇÁZ, M., 1995: Rozmnožování [Reproduction]. In: BARUŠ, V., OLIVA, O. (eds.) et al., 1995: Fauna 
ČR a SR, sv. 28/1. Mihulovci - Petromyzontes a ryby Osteichthyes (1). Academia Praha, pp. 231-275 (in Czech).

PEŇÁZ, M., 2001: A general framework of fish ontogeny: a review of the ongoing debate. Folia Zool., 50(4): 241-256.

POLICAR, T., KOZÁK, P., HAMÁČKOVÁ, J., LEPIČOVÁ, A., LEPIČ, P. \& KOUŘIL, J., 2004: Vliv délky období živého krmení na přežití a růst larev jesetera sibiřského (Acipenser baerii) [The effect of duration of live feeding period on the survival and growth of Siberian sturgeon (Acipenser baerii) larvae]. In: Spurný, P (ed.), "55 years of the study programme of the fishery specialization at Mendel University of Agriculture and Forestry in Brno". MUAF Brno, pp. 90-98 (in Czech, with English abstract).

PROKEŚ, M., BARUŠ, V. \& PEŇÁZ, M., 1996: Growth of larvae and juveniles 0+ of Siberian sturgeons (Acipenser baeri) in aquaculture and experimental conditions of the Czech Republic. Folia Zool., 45(3): 259-270.

PROKEŠ, M., BARUŠ, V. \& PEŇÁZ, M., 1997a: Comparative growth of juvenile sterlet (Acipenser ruthenus) and Siberian sturgeon (Acipenser baerii) under experimental conditions. Folia Zool., 46 (2): 163-175.

PROKEŠ, M., BARUŠ, V. \& PEŇÁZ, M., 1997b: Growth of $0+$ juveniles Russian sturgeon (Acipenser gueldenstaedti) in experimental basin conditions (Czech Republic). Folia Zool., 46(4): 337-351.

PROKEŠ, M., BARUŠ, V. \& PEŇÁZ, M., 1999: Morphometry, systematics and growth parameters of sturgeons (Acipenseriformes) introduced in the Czech Republic. In: Bienial Report 1997-1998. Institute of Vertebrate Biology AS CR, Brno 1999, pp. 19-21 (in Czech, with English abstract).

PROKEŠ, M., BARUŠ, V. \& PEŇÁZ, M., 2000a: Akvakulturní chov jeseterů v České republice [Aquaculture of sturgeons in the Czech Republic]. In: Mikešová, J. (ed.), Sb. The 4th Czech Conference of Ichtyology Vodñany 10-12. May 2000. Research Institute of Fish Culture and Hydrobiology University of South Bohemia in Vodňany, pp. 140143 (in Czech, with English abstract).

PROKEŠ, M., BARUŠ, V. \& PEŇÁZ, M., 2000b: Morfometrická a růstová rozmanitost u druhů jeseterů chovaných v České republice v letech 1994-1999 [Morphometry and growth variety of sturgeon species reared in the Czech Republic in
1994-1999]. In: LUSK, S. \& HALAČKA, K. (eds.), Biodiversity of fishes in the Czech Republic (III). Institute of Vertebrate Biology, Academy of Science of the Czech Republic, Brno, pp. 131-138, ISBN 80-2385659-6 (in Czech, with English abstract).

PROKEŠ, M., BARUŠ, V., PEŇÁZ, M. \& BARÁNEK, V., 2003a: Růstové vlastnosti a problematika chovu jesetera sibiřského (Acipenser baerii) v podmínkách České republiky [Growth rate and rearing problems of Siberian sturgeon under conditions of the Czech Republic]. Bulletin, Research Institute of Fish Culture and Hydrobiology in Vodňany, 2003: 99-103 (in Czech, with English abstract).

PROKEŠ, M., BARUŠ, V., PEŇÁZ, M., BARÁNEK, V., OŠANEC, J. \& ŠUTOVSKÝ, I., 2003b: Biometrie a růst jesetera malého (Acipenser ruthenus) v České republice [Biomorphometry and growth rate of the sterlet (Acipenser ruthenus) in the Czech Republic]. In: ŠVÁTORA, M. (ed.), Sb. The 6th Czech Conference of Ichtyology, Praha 2003, pp. 81-86 (in Czech, with English abstract).

PROKEŠ, M., BARUŠ, V., PEŇÁZ, M., JIRÁSEK, J., \& MAREŠ, J., 1997c: Growth of juvenile Siberian sturgeon (Acipenser baerii) fed two types of pelleted feed under trough farming conditions. J. Anim. Sci., 42: 501-510.

PROKEŠ, M., BARUŠ, V., MACHOLÁN, M., KRUPKA, I. \& MASÁR, J., 2002: Meristic and mensural morphometrical characters of juvenile sterlet reared in the Czech Republic and Slovak Republic. Folia Zool., 51(2): 149-164.

PŠENIČKA, M., RODINA, M. \& LINHART, O., 2010: Ultrastructural study on the fertilisation process in sturgeon (Acipenser), function of acrosome and prevention of polyspermy. Animal Reproduction Science, 117: 147-154.

STRÁŇAI, I., 1992: Rast jesetera malého s ohl'adom na dİ̌ku jeho rostra [Growth of sterlet with respect to the length of its rostrum]. In: Nagy, Š. (ed.), Sb. Referátov z konferencie ichtyologickej sekcie SZS. Vydala IS SZS pri SAV, Bratislava 1992, pp. 39-46 (in Slovak).

WEGNER, A., OSTASZEWSKA, T. \& ROŻEK, W., 2009: The ontogenetic development of the digestive tract and accessory glands of sterlet (Acipenser ruthenus L.) larvae during endogenous feeding. Reviews in Fish Biology and Fisheries, Volume 19, Number 4 (2009): 431-444.

\section{Address}

Ing. Juraj Rybnikár, doc. Dr. Ing. Jan Mareš, Ing. Martin Cileček, Ústav zoologie, rybářství, hydrobiologie a včelařství; Mendelova univerzita v Brně; Zemědělská 1, 61300 Brno, Česká republika, Ing. Miroslav Prokeš, CSc., Ústav biologie obratlovců Akademie věd ČR, v.v.i., Brno, Květná 8, 603 65, Česká republika, e-mail: xrybnika@node.mendelu.cz,mares@mendelu.cz,xcilecek@node.mendelu.cz,prokes@brno.cas.cz 
